\title{
The Effects of Warm-Up Tasks on the Iranian EFL Students' Writing Ability
}

\author{
Zahra Pakdel Estalkhbijari \\ M.A. in TEFL, Islamic Azad University- Tonekabon Branch, Iran \\ E-mail: Pakde189@yahoo.com
}

Mohammadreza Khodareza

Ph.D. Candidate in TEFL, Islamic Azad University-Khorasgan Branch, Iran

E-mail: mkhodareza@yahoo.com

Received: August 9, 2011 Accepted: August 16, $2011 \quad$ Published: April 1, 2012

doi:10.5539/ies.v5n2p190 URL: http://dx.doi.org/10.5539/ies.v5n2p190

\begin{abstract}
This study aims to investigate the effects of warm up tasks as classroom activities on foreign language written production. For showing these effects, sixty out of one hundred forty Iranian sophomore EFL students from the Islamic Azad University of Lahijan branch, Iran were selected after following the Oxford Placement Test (OPT). Then, they were randomly divided into two groups; the experimental group who received the treatments on warm up tasks, and the control group who received a placebo. Both groups had to write two paragraphs of about 150 words that were considered as their pretests and posttests. The paragraphs were corrected by three experienced raters. Their scores analyzed through SPSS by applying Independent t-test, and Paired sample t-test. The findings revealed that participants in the experimental group, who had received the treatments on warm up tasks, significantly enhanced better performance in a writing test.
\end{abstract}

Keywords: Warm up task, Writing skill, Class activity, Placebo, EFL students

\section{Introduction}

In terms of skills, producing a coherent, fluent, extended piece of writing is probably the most difficult thing there is to do in languages. It is something most native speakers never master. For second language learners, the challenges are enormous, particularly for those who go on to a university and study in a language that is not their own (Nunun, 1999). Written products are often the results of thinking, drafting and revising procedures that require specialized skills, skills that not every speaker develops naturally (Brown, 2001). We must realize that writing a language comprehensibly is much more difficult than speaking it (Rivers, 1981).

According to Halliday (1985), writing emerged in societies as a result of cultural changes that created new communicative needs. Rivers (1981) believes that writing in the language becomes more complicated when it involves writing meaningful segments of language which might be used in specific circumstances. Ziahosseiny (2007) states that writing is an extremely complex cognitive activity in which the writer is required to demonstrate control of a number of variables simultaneously. Nanun (1989: 36) believes that "at the sentences level these include control of content, format, sentence structure, vocabulary, punctuation, spelling and letter formation. Beyond the sentence level, the writer must be able to structure and integrate information into cohesive and coherent paragraphs and texts".

In the history of language teaching, there have been numerous approaches to the writing instruction. Traditionally, writing was viewed mainly as a tool for the practice and reinforcement of certain grammatical or lexical patterns, a rather one-dimensional activity in which accuracy was all important and content and self expression were trivial. However, with an increase in attention to students' practical needs born out of functional-notional approaches, the significance of writing certain text types as a skill was highlighted (Holmes, 2006: cited in Alifatemi, 2008). With so many conflicting theories around and so many implementation factors to consider, planning and teaching a course in writing can be a daunting task (Richards and Renandya, 2002: 303). Alifatemi (2008) also mentions, "as it is an important productive skill through which thoughts and ideas are disseminated, it is incumbent for instructors of 
writing in different educational environments to exploit the many different methods, approaches and techniques that can serve to produce better writers".

According to the university syllabus for TEFL, the ultimate goal of teaching English in Iran is to enable the learner to communicate effectively in both the oral as well as the written mode of the language (Yarmohammadi, 1995; Saffarzadeh, 1985 as cited in Alifatemi, 2008). However, there is much evidence that the objectives of the syllabus are rarely attainable and Iranian students often have problems with the oral mode as well as with the written form the English language. There are a variety of factors contributing to this problem among Iranian EFL sophomores.

Firstly, there is a distinct absence of mastery of both the macro and micro skills of writing. This is attested to Birjandi, Alavi and Salmani (2004) who note that Iranian learners of English may have problems not only in Macro-skills (content, and organization), but also in Micro-skills (grammar, vocabulary, and mechanics) of writing. Further evidence of this deficiency in both the micro and macro skills have been gleaned via CA (Yarmohammadi, 2002; Ziahosseiny, 1994; Keshavarz, 2003; Fallahi, 1991; and Faghih, 1997 as cited in Alifatemi, 2008).

The problem is further exacerbated by the dominant method of teaching language i.e., the Grammar-Translation Method (Hassani, 2003 as cited in Alifatemi, 2008) which is mainly grammar based and hence focuses only on teaching language through translation and neglects teaching other language skills such as listening, speaking and writing. Consequently, the translation mode is the predominant tool used in the writing process and this invariably contributes to the generation of poor quality written output containing grammatical errors and even communicative failures due to the inherent differences between the two languages (Yarmohammadi, 2002; Birjandi et al. 2004 as cited in Alifatemi, 2008).

Some researches over the last 25 years in Iran has provided insights that the product approach which dominates the writing teaching language scene has contributed to the deterioration in the quality of writing. Also, teachers' attitude towards correcting learners' writing is nothing but time consuming and unrewarding as learners usually repeat the same errors even after getting the feedback of error correction. All these problems may further compound the problem.

According to Hassani (2003: 4, cited in Alifatemi, 2008), the following problems exist in the Iranian language learning environment:" a) unqualified teachers, b) old methods of teaching, c) differences in cultures, d) non-authentic materials, e) lack of audiovisual facilities, f) lazy pupils, g) the lack of native speakers, and h) the lack of satellite channels to watch English language programs". Moreover; some part of the writings of Iranian learners may appear to be a word for word translation of the Persian language structure into English. In the process of writing, learners may make errors rooted in their mother tongue (Yarmohammadi, 2002 as cited in Alifatemi, 2008).

It appears that all the problems cited above have affected the Iranian EFL sophomores' English language proficiency which is defined by Richards et al. (1992: 204) as the degree of skill with which a person can use a language, such as how well a person can read, write, speak, or understand language.

The finding of a study which was completed at the university of Isfahan revealed that participants in the instruction-task group performed significantly better than those in argumentative-task group in terms of fluency and accuracy. In addition, analysis of complexity measures showed that argumentative essays were produced with more complex language than the instruction essays (Rezazadeh, Tavakoli, Eslami, 2011: 169).

Warm-up activities will help students to turn off the outside world and focus on the task at hand. By the end of the warm-up activity, every student will be ready to learn and being able to focus on their language lesson. In any classroom, there always are students who are more reticent and are willing to let others do all the participating. By engaging students to take part in a low-risk, warm-up activity, a teacher will reach every student and will help their students achieve their language goals. He also says a warm-up activity is the perfect time to review language skills presented in the previous English lesson (Leblanc, 2011). According to Flanigan (2011) performing warm-up activities in English class will help students be in the right frame of mind to learn. Also proper warm-up activities ensure that students will get the most from their class.

In the age of Internet, information technology and globalization, writing in English has become so important (Mourtaga, 2011). However, it seems that many EFL instructors and supervisors in Iran still misunderstand the essence of the writing process. Many of them use traditional approaches based on memorizations and drilling.

\section{The Purpose of the Study}

In terms of skills, producing a coherent, fluent, extended piece of writing is probably the most difficult thing there is to do in languages. It is something most native speakers never master. For second language learners, the challenges are enormous, particularly for those who go on to a university and study in a language that is not their own (Nunun, 1999). 
The present study investigates Warm-Up tasks as an activity that presumed to play a role in EFL writing classes. The question this study tries to answer is whether or not providing students with Warm-Up tasks as their classroom activities will exert any impact on their writing skill. According to Peterson (2010), "beginning your lesson plans with a five-minute warm-up can serve to focus your students on the topic, open up creative thinking and help them to apply the learning in new ways. The feedback you get from students also gives you an instant reading on where their heads are. Warm-ups help your learners put aside their daily distractions and focus on English. If they haven't used English all day, they may take a little while to shift into it. Warm-ups also encourage whole-group participation which can build a sense of community within the group.

According to Leblanc (2011) Warm-up activities will help students to turn off the outside world and focus on the task at hand. By the end of the warm-up activity, every student will be ready to learn and being able to focus on their language lesson. In any classroom, there always are students who are more reticent and are willing to let others do all the participating. By engaging students to take part in a low-risk, warm-up activity, a teacher will reach every student and will help their students achieve their language goals.

Good English writing skills can open up a lot of rewarding opportunities for you. English is pretty much a universal language. It is the language of business. And good communication skills in written English can allow you the access to opportunities on a global scale that you may not even know existed. From corresponding to networking, the more knowledgeable you are in English writing, the more successful you can be.

The purpose of present study is to examine how warm-up tasks affect EFL students' writing ability. In doing so, it attempts to investigate whether the results obtained will confirm the finding of previous studies in language learning settings.

\section{Research Question and the Hypotheses of the Study}

Based on the problems and purpose discussed above, the following research question was addressed:

Q) Does providing students with warm-up tasks have any effect on their writing skill?

The research question of this study can result in the following three hypotheses:

H1) There is no significant difference between the mean scores of the writing skill of the learners who will be given warm-up tasks as their classroom activity and the learners who are not in Lahijan population (null hypothesis).

H2) There is a progress in the experimental group from the pretest to the posttest of the study in Lahijan population.

H3) There is no progress in the control group from the pretest to the posttest of the study in Lahijan population (null hypothesis).

\section{The Significance of the Study}

In the age of Internet, information technology and globalization, writing in English has become so important (Mourtaga, 2011). However, it seems that many EFL instructors and supervisors in Iran still misunderstand the essence of the writing process. Many of them use traditional approaches based on memorizations and drilling. The English language is a complicated language. With all the rules and exceptions, writing in the English language can be very challenging. Learning to writing well in the English language could take many years, even decades of practice in order to be proficient in English writing. Writing is hard enough even in mother tongue, so rather daunting a task in a foreign language. Thus, helping students to develop writing skills is a demanding enterprise for teachers. Having a good warm-up activity is important to an English language lesson, as it sets the student up for success on many different levels.

Writing is difficult as it requires intense, active thinking throughout a continuous productive process in which thought and ideas are transferred into written communication, but not just words and letters on paper. However, more often than not, students "believe that writing is a natural gift rather than a learned skill" (Langan, 2000: 12, cited in Alifatemi, 2008). They may add that they do not have the talent of writing. As a result, these students do not write and do not try their best to do so. Nevertheless, the good news is that writing can mastered through practice, and all what it needs is special attention from both instructors and students.

According to Leblanc (2011) Warm-up activities will help students to turn off the outside world and focus on the task at hand. By the end of the warm-up activity, every student will be ready to learn and being able to focus on their language lesson. In any classroom, there always are students who are more reticent and are willing to let others do all the participating. By engaging students to take part in a low-risk, warm-up activity, a teacher will reach every student and will help their students achieve their language goals. According to Flanigan (2011) performing warm-up activities in English class will help students be in the right frame of mind to learn. Also proper warm-up activities ensure that students will get the most from their class. 
Presently, there is a dearth of information pertaining to the actual status of writing competency, language proficiency, and grammatical errors of Iranian learners. By studying the students' performance in writing and proficiency tests, this study could reveal the actual state of Iranian EFL learners' level of English language proficiency and their writing competence, as well as establish the variables most correlated with writing.

Moreover, the findings of this study can be used as a benchmark to compare Iranian EFL learners' knowledge of English with other foreign language users in other contexts.

This is a significant finding since the evidence of strong correlation between writing and other variables suggest that each of them can be a predictor for writing (Gay, Mills, and Airasion, 2003: 333). This means that the performance of the learner in other variables can be predicted through his performance in writing or vice versa.

This study also serves to help teachers to better structure their lesson plans by providing them with data about the problem areas that affect their students.

The results of this study are useful for intermediate EFL students at universities and language learning institutions. Also it could be effective for high school and advanced school students who must learn English.

\section{Definitions of Key Terms}

Before we start our investigation of the warm-up tasks on the writing skill, it is necessary to clarify some of the fundamental concepts involved in it.

\subsection{Warm-up Task}

To engage in exercise or practice especially before entering a game, contest or lesson for preparing students to do something.

Preparing audiences so as to make them more receptive to the main act. This is done by the teacher to attract students' attention. If a lesson starts with a warm-up activity, it will become enjoyable and interesting.

Different types of warm-up activities and exercises include journal, bell work, tic-tac-toe, mysterious object descriptions, timer, free writing, clustering, writing reviews, observing and eavesdropping, writing a scene from a day, different perspectives, three wishes and historical narrative.

\subsection{Writing Skill}

Writing is a complex process that allows writers to explore thoughts and ideas, and make them visible and concrete. Thinking is the foundation of writing and, because thinking is central to learning, students who are able to make their thought processes concrete through writing enhance their learning capabilities.

Writing is a productive, creative and recursive skill which involves a complex web between writer, reader, reality and text. During the writing process, students engage in pre-writing, planning, drafting, and post-writing activities. However, as the writing process is recursive in nature, they do not necessarily engage in these activities in that order.

In its most highly developed from, writing refers to the conveying of information or the expression of original ideas in a consecutive way in the new language. This is called expressive writing or composition. Composition may be for practical purposes (the writing of instructions, reports, resume, concrete description or essential correspondence connected with every day affairs), or it may be more creative (Rivers, 1981).

\subsection{Class Activity}

It refers to students participating in different activities such as game, role play, warm-up, discussion and etc which are done in the classroom.

\subsection{Placebo}

An inactive instruction or preparation used as a control in an experiment or test to determine the effectiveness of a treatment.

Any group used as a control in a statistical experiment who receives either a placebo or a standard instruction during an investigation of the effects of another instruction on other group (experimental group).

An inactive instruction administered to a control group usually to compare its effects with those of a real treatment, but sometimes for the psychological benefit he is receiving treatment.

\subsection{EFL Students}

EFL students refer to students of the university in Iran, Lahijan, who study English as a Foreign Language. 


\section{Method}

\subsection{The Design of the Study}

One hundred forty sophomore students of translation training program studying at the Islamic Azad University (IAU) of Lahijan branch, Iran took part in the study. They were both male and female with the age range of 20_23, and their average age was 21 years and 6 months. All participants were foreign language learners of English, all of whom have been learning language in a classroom setting. Following an Oxford Placement Test (OPT), intermediate level learners were selected for the study. The test contained 60 multiple choice items, and it was used to enable the researcher to select a homogeneous group. This test consisted of grammar (20 items), vocabulary (20 items), reading comprehension ( 20 items). The allotted time for answering the questions was 45 minutes. After correcting the papers, 60 students were selected as the intermediate group based on the OPT manual (Those participants whose grades were among 12 to 22 (total grades $=30$ ) were selected).

Afterwards, the selected participants were randomly assigned to two groups of 30 to form experimental and control groups of the study. The study took place during one semester at university (thirteen sessions), and was carried out simultaneously by the two teachers participating in it. At the end of each lesson, students were asked to write a paragraph of about 150 words individually or in small groups. All data were collected during normal class times by course instructors. This research applied a quantitative and quasi-experimental design.

\subsection{Participants}

\subsubsection{Experimental Group}

Participants in the experimental group were thirty sophomore students of translation training program from Islamic Azad University of Lahijan branch, Iran. After following the OPT, they were selected. All participants in the experimental group received treatment on warm up tasks. About half of the class time was allotted to working on such warm up tasks.

\subsubsection{Control Group}

These participants were thirty sophomore students of translation training program from Islamic Azad University of Lahijan branch, Iran. They also were selected after following the OPT. The participants in control group received no treatment on warm up tasks. They spent the whole time of the class just to learn the rules of paragraph writing.

\subsection{Materials and Procedures}

For implementing writing tasks, we decided to follow Kemmis and McTaggart's model (as cited in Nunan, 1989: 73), which considers four main aspects as follows:

- To develop a plan of action to improve what is already happening. To do so, we designed a chronogram including the necessary aspects to be worked: The pedagogical strategy and the necessary tools to explore what happened during such implementation.

- To act to implement the plan. In this step, we not only designed the lesson plans, including warming up activities, but also developed them with the chosen groups.

- To observe the effects of action in the context in which it occurs. This was done by means of class observation, and writing paragraphs at the end of each lesson.

- To reflect on the effects of the use of warm ups as a basis for further planning and subsequent action, through a succession of cycles. To do so, after each class we gathered information to analyze what we had observed in relation to the effects of the warm up and shaped our plan for the next one.

To try to increase motivation and the students' involvement during the class, so that they could have more tools to improve their language learning process. All of these efforts allowed teacher or researcher to have new available activities useful to be applied in the daily work as the ones included in the lesson plans (see a sample in Appendix 2).

We asked experimental group participants about the activities that encouraged them to work in the class, and the ones they liked the most to start it in diagnostic questionnaire that we applied at the beginning of our project (see Appendix 1). The results can be seen in table 1.

Based on the information gathered in the diagnostic stage, we created some warm up activities for the implementation stage. They were organized according to the aspects we considered important for our research (see table 2).

After three sessions of teaching the basic rules of paragraph writing to both experimental and control groups, they 
were assigned to write a paragraph of at least 150 words in 20 minutes about the topic their teacher had determined to them at the last of the third session. They were allowed to use their dictionaries. It was considered as their pretest.

From the fourth session on, just one group which was randomly assigned as the experimental group was treated via the determined warm up tasks. We considered three sessions for routines and daily activities, three sessions for activities related to topics, two sessions for informal conversation, and two sessions for formal conversation. Students had to think and answer some questions related to the topic which was made by the teacher. Also they had to participate in class activities by answering the question, by walking in the class, by matching pictures and guessing words, by drawing on the board or on paper. We provided some lesson plans for routines and daily activities for fourth, fifth and sixth sessions (see one sample in Appendix 2).

For other three sessions, we determined three topics they had more interest in (pierced, abortion, and computer nut), and then we share information about the topics. Next sessions we asked them to tune into other people's conversation everywhere they liked, for example, in the university, in the street, in the bus, in the bookstore, and etc. It's not only about the words they say, but the emotion they put into it. This is a great way to get ideas for a character's background or motivation.

Then, we asked them to read a book at home and shared information about the characters and the formal expressions and structures used in the book and played rules in the class and then wrote a review.

We should notice that from fourth session on, we spent 25 minutes of every session on explanation rules of paragraph writing, 5 minutes for free time, 30 minutes for warm up tasks, 20 minutes for writing, and 10 minutes for writing evaluation. While the control group spent whole time of the class just to learn the rules of paragraph writing, and they wrote some paragraphs individually or in small groups. However, their paragraphs were corrected in the class.

Peer evaluation of writing helps learners to become aware of an audience other than the teacher. Other learners to comment on what they liked/didn't like about the piece of work, or what they found unclear. The teacher can also respond at this stage by commenting on the content and the organization of ideas, without yet giving a grade or correcting details of grammar and spelling. After ten sessions of working in this way, both groups were assigned to write a paragraph of 150 words in 20 minutes on the topic their teacher determined to them. It was considered as their posttests.

\subsection{Scoring}

After ten sessions of working in this way, both groups were assigned to write a paragraph which was considered as their posttests. It should be noted that the 120 English paragraphs (60 paragraphs for pre-tests, and 60 paragraphs for posttests of experimental and control groups) were related to six major components of writing on a 20 -score scale, a modified version of the analytic method introduced by Hughes (1989) as illustrated in table 3.

We applied inter-rater reliability for scoring students' writing. All 120 paragraphs (60 paragraphs for pre-tests, and 60 paragraphs for posttests), were scored by three experienced writing instructors. Then, the average score of every paragraph was used in the data analysis.

\subsection{Data Analysis Procedures}

The first instrument designed was a questionnaire (Appendix 1). As we already explained, it was elaborated in order to identify some aspects related to the students' point of view about the class stages, the activities they liked the most, and the ones that helped them to become involved during the class process.

According to this preliminary stage, we found that most of the students had more interest in activities that implied movement or those like mimics, or guessing, to start the class. In addition, they apparently preferred working in small groups. Also, they suggested games or dynamics, and varied activities to have a good start in the lesson. It seemed that these activities could encourage them to understand better, increase their attention and interest and promote interaction among classmates.

Students appeared to have interest in activities that motivated, caught their attention and increased their understanding. Those findings were very relevant when preparing the warm up as it could be noticed in the lesson plan sample included in Appendix 2. Each one of the lesson plans was designed according to the stages described before and taking special care of the warming ups selection process. Based on the results of the questionnaire, we continued the process of data collection as described before.

All 120 paragraphs (60 paragraphs for pre-tests, and 60 paragraphs for posttests), were scored by three experienced writing instructors. Then, the average score of every paragraph was used in the data analysis. The data gathered in this study (60 scores for pre-tests, and 60 scores for posttests), were analyzed through SPSS. For examining the 
effects of the treatment, independent t-test was used. Also, for showing the progress from pre-test to posttest in both control and experimental groups, two paired sample t-test were applied.

\section{Results and Discussion}

Based on our research question, and according to the first hypothesis, we need mean scores of both groups, so we use descriptive statistics, and then independent t-test for accepting or rejecting our first hypothesis. As you can see in table 4, the mean score of the experimental group is equal 17, and the mean score of control group is equal to 14.59. In independent samples test, the mean difference between two groups is equal to 2.408 , and that is high enough to reject our hypothesis. Also the amount of $t_{o}(10.53)$, is higher than $t_{c}(2.04)$ in $p<0.05\left(t_{o}>t_{c}\right)$, so our null hypothesis is rejected. As a result, the significant difference between mean scores of control and experimental group approves the significant effect of warm up tasks on the experimental group.

For second and third hypotheses, we need paired samples test because experimental and control groups are considered as two dependent population. Tables 4 and 5 reveal the results of the second and third hypotheses in sequence. Table 5 reveals the results of the second hypothesis. As you can see in table 5 , there is a progress from the mean scores of the pretest to the posttest in the experimental group. Also the amount of $t_{0}$ is equal to 27.82, and that is high enough $\left(\mathrm{t}_{0}>\mathrm{t}_{\mathrm{c}}\right)$ to accept our hypothesis in $\mathrm{p}<0.05$ which approves the significant progress from the pretest to the posttest in experimental group.

As you can see in table 6 , the amount of $t_{0}$ is less than $t_{c}\left(t_{0}<t_{c}\right)$ in $p<0.05$, and so the third null hypothesis is supported. As you can see in table 6 , there is a little progress from mean scores of the pretest to the posttest in the control group, so it is not high enough to prove that there is a significant progress from the pretest to the posttest in this group.

As a result, the statistical analyses of hypotheses revealed that providing students with warm up tasks have significant effect on their writing ability. We based our observation on suggestions given by Nunan (1989), who recommends organizing the findings in categories as they are analyzed. The collection and later analysis of the gathered information led us to identify key aspects in relation to the role of warm up activities in students' involvement in the English class. We organized information into four main categories: strengthening knowledge about language, students' involvement, interaction, and values.

(1) Strengthening Knowledge about Language: This category is related to the language competence; that is to say, acquiring pronunciation, structures, and functions. This category is also closely related to cognitive processes like memorization, establishing relations and concentration, which emerged when students participated in the warm ups. We found in the students posttests that they thought they learnt different aspects of language according to the warm ups worked in class. For example, in the class where the daily activities were applied, students said they had learnt vocabulary. Likewise, in the class where eavesdrop was played, most of them said they had learnt to describe sensations and some others mentioned gains in spelling.

The aspect of paragraph construction and language structures learned was also evidenced in the data collected. As can be noticed, functions and structures were learned easily as a result of the use of funny and enjoyable activities, combined with other important communicative aspects. That means the warm up let teachers link the way language can be used with its formal construction (structures). As mentioned by Howatt (1994), it is not merely a question of activating and exciting but of stimulating the development of the language system itself.

(2) Students' Involvement: This refers to the range of engagement that students had with the whole class. Here, two subcategories were drawn: participation and individual work.

Participation: This refers to continuous students' contributions to the class, by answering questions related to particular topics or situations. They took part in the activities, encouraged each other and took turns participating in problem-solving activities.

Individual work: This refers to learners' engagement with the activities in an individual way. Students got involved in writing, drawing, speaking, trying to memorize, and getting information and being focused on fulfilling the objective of the lessons. Making reference to individual work and written production, a good number of students appeared to be interested in doing activities in their notebooks. Besides, it could be noticed that individual work later contributed to group work. After fulfilling the goals set out for individual tasks, when they worked as a group, students also contributed to task completion by looking for notes in their notebooks' or just giving suggestions.

Also, the analysis of the students' posttests showed that warm up activities produce positive feelings such as happiness, motivation and excitement.

(3) Class Interaction: This category is related to how the students tried to get information as well as how they shared 
knowledge or information. The students showed they interacted in order to get actively involved in the warm up activities.

During the implementation stage, we also observed that students continuously asked the teacher questions. The students wanted to be explained exactly what to do. Likewise, students' attitude was remarkable during this time; it was always positive; they tried to answer the questions asked by the teacher in the different class stages. Several students went to the center and a student helped to check who was right or wrong. On the whole, students seemed to actually enjoy the classes because the general vision was a class drawing, writing, talking or listening carefully whenever the class activities required doing so.

(4) Values' Reinforcement: Values are understood as one's principles, priorities, or standards. We refer here to how the warm up promoted the reinforcement of human values like honesty, self-confidence and responsibility. During the development of the classes, students encouraged each other. Also, when they participated in the activities they respected their turns and seemed to be engaged in the activities proposed.

\section{Conclusion}

This study investigated the effects of warm up tasks on the writing ability of two groups of Iranian EFL students. Through the analysis of the findings gotten from the students' pretests and posttests, we have come to the conclusion that the role of warm ups is one of being an attention injector for students. That facilitates their involvement in the class work by sharing answers, trying to participate, paying attention, giving the answers, encouraging to take part in the lesson, participating as volunteers, working on the exercises, drawing, and writing the exercises. The findings revealed that participants in the experimental group, who had received the treatments on warm up tasks, significantly enhanced better performance in a writing test.

\section{The Implications of the Study}

At the end of this study, we as researchers could assert that using warm up activities is an effective way of helping students to begin the English class daily. In regards to this, we completely agree with Allwright (1984: 162) who concluded, based on her own experience, that "with warm ups students paid closer attention, asked better questions and seemed a bit more excited than before" (p. 162). This author also claims that "the proper presentation of warm ups will cause people to stop whatever they are doing or thinking and refocus their attention" (p. 164), an aspect that could be confirmed through the findings of this study.

Based on the results collected mainly in the class these kinds of activities really appear to promote students' involvement in the English class. They must be used as a motivation and a means of preparing the ground for the various stages of the lesson. As could be noticed in the lesson plan (Appendix 3), they are neither long tasks nor an explanation of the topic. In the same way, they must not be considered as isolated stages in the process or be centered on only one skill. That means we can prepare the warm up with the objective of involving students' participation and letting them communicate at an early stage of the lesson.

Some important aspects to be considered for the warm up development are the classroom conditions and the clarity of the activity rules, particularly if they are games or competitions to avoid confusion among students. That means we have to explain the procedure carefully before starting, to have all the materials ready, to encourage students to participate and to motivate them by means of examples or guides.

It is also important to remark that no matter how simple warm up activities can be, they should be well prepared. In addition, we need to examine the connection for the later activities so that we, as teachers, can take advantage of them to develop our lessons. For example, to prepare the warm up related to the use of Daily activities and their frequency, the teacher only had to think about the sentences the students must include in this activity and the right order to develop the activity. Consequently, it did not demand a lot of time to prepare or complicated materials to be implemented.

We can promote students' involvement at the very beginning of the class by applying warm ups. And for warm ups to be effective they should be short, related to the topic, useful to continue later activities, interesting, and enjoyable. In doing so, we can prepare students to concentrate and to help them begin to think and focus their attention on the English class.

\section{Limitations of the Study}

Due to its own particular features, this study has certain limitations:

- Firstly, this study was restricted to learners who were EFL sophomores of Translation training Program in order to control the internal validity of the research.

- Secondly, based on literature, this study recruited students with intermediate English proficiency. Therefore, the 
findings of the present study cannot be generalized to apply to L2/FL learners with low or high proficiency levels. In order to examine this issue, a future study could include participants with different proficiency levels.

- Thirdly, this study was limited to the Islamic Azad University of Lahijan branch; and its findings cannot be generalized to apply to all Iranians, although the sample was representative of the population under the study due to its random nature.

- Another limitation of this study was the fact that, we only included one task in each session.

- Yet another limitation of this study was its one-time writing format and its administration as a test. This might have prompted learners to utilize avoidance strategy in their writing. However; to control this problem, the researcher announced that the result would not be publicly announced, but only privately to the learners themselves to let them get feedback on their performance and it had nothing to do with grading and that it was only for the sake of conducting a research.

\section{Suggestions for Further Studies}

The study here indicated that the warm-up tasks play a significant role in L2 writing. Whatever has been done as experiments, will help the researchers move toward finding more effective uses of warm-up tasks to improve the students writing ability. However, further replications of such studies will provide us with broader perspective regarding the issue. No matter how much contribution a study makes to a field, there is always room for improvement.

- Firstly, limitation of this study was the fact that, we only included one task in each session; therefore, future research should include multiple tasks per sessions, in order to determine students' writing ability differs between types of tasks.

- Secondly, this study was restricted to learners who were EFL sophomores of Translation Training program were studying in Islamic Azad University in Lahijan branch, so, the future research should include EFL students of different majors in different universities.

- Thirdly, it would be wise to include several levels of L2 proficiency or writing skill in future research. Our participants were all sophomore English students at University, which implies that they had all attained a certain level of L2 proficiency, and, therefore, our comparison between writers was really a comparison of writers at a similar level.

\section{References}

Airasian, P. Gay, L. R., \& Mills, G. E. (2003). Educational research: Competencies for Analysis and Application, $7^{\text {th }}$ ed. Upper Saddle River, NJ, Pearson Education. 333.

Alifatemi, M. (2008). The Relationship between Writing Competence, Language Proficiency And Grammatical Errors in the writing of Iranian sophomores. Published Dissertation. University Sains Malaysia.1-20.

Allwright, R. (1984). The importance of interaction in classroom language learning. Applied Linguistics, 5(2), 156-171. http://dx.doi.org/10.1093/applin/5.2.156

Birjandi, P., Alavi, S. M., \& Salmani, M. A. (2004). Advanced Writing. Tehran, zabankadeh Publications.

Brown, H. D. (2001). Teaching by Principles: An Interactive Approach to language Pedagogy. San Francisco State University. 334-356.

Flanigan, E. (2011). The Importance of Warm up Activities in English Class. [Online] Available: http://www.ehow.com (July 5, 2011)

Halliday, M. (1985). An Introduction to Functional Grammar. London: Arnold.

Howatt, J. W. (1994). Our criteria for grading students' programs. ACM, SIGCSE Bulletin, 26(3), 3-7. http://dx.doi.org/10.1145/187387.187389

Leblanc, R. (2011). The Function of Warm Up Activities for Learning English. [Online] Available: http://www. ehow.com (June 11, 2011)

Mourtaga, K. R. (2011). Poor Writing in English: A Case of the Palestinian EFL Learners in Gaza Strip. Published article. [Online] Available: http://www.qou.edu/english/conferences

Nunan, D. (1989). Understanding language classrooms. New York: Prentice Hall. 36.

Nunan, D. (1989). Understanding Language Classrooms: A Guide for teacher-initiated action. London: Prentice Hall International (UK) Ltd. 73. 
Nunn, D. (1999). Second Language Teaching and Learning. Boston, Massachusetts: Newbury House Teacher Development.

Peterson, D. (2010). Warm-Up Exercises. [Online] Available: http:// www.TeachingJobs.com (September 17, 2010)

Rezazadeh, M., Tavakoli, M., \& Eslami Rasekh, A. (2011). The Role of Task Type in Foreign Language Written Production: Focusing on Fluency, Complexity, and Accuracy Published article, Vol. 4, No, 2. Canadian Center of Science and Education. 169-176. http://dx.doi.org/10.5539/ies.v4n2p169

Richards, Jc., \& Renandya, W. A. (2002). Methodology in Language Teaching. Cambridge: Cambridge University Press. 303-305.

Rivers, W. (1981). Teaching Foreign Language Skills. Chicago: The University of Chicago Press.

Ziahosseiny, S. M., \& Salehi, M. (2007). An investigation of the relationships between motivation and language learning strategies by university students. Pazhoheshe-zabanhahye khareji, 41, 89-104.

Table 1. Activities that encourage students to work in class

\begin{tabular}{|l|l|l|}
\hline \multicolumn{1}{c|}{ Activity } & Students (N) & \multicolumn{1}{c|}{ Percentage } \\
\hline Activities that implies movement & 11 & $36.6 \%$ \\
\hline Activities related to the topic & 9 & $30 \%$ \\
\hline Informal conversation & 6 & $20 \%$ \\
\hline Formal conversation & 3 & $10 \%$ \\
\hline Other & 1 & $3.4 \%$ \\
\hline & Total N=30 & Total $=100 \%$ \\
\hline
\end{tabular}

Table 2. Warm up activities implemented during the project.

\begin{tabular}{|l|l|}
\hline \multicolumn{1}{|c|}{ Topic } & \multicolumn{1}{c|}{ Warm up } \\
\hline Routines and daily activities & $\begin{array}{l}\text { Matching pictures to expressions, guessing, to share information about } \\
\text { routines, and to identify specific information in a text. }\end{array}$ \\
\hline Activities related to the topic & $\begin{array}{l}\text { Explanation to the topic, question and answer, to share information about } \\
\text { the topic, drawing some pictures. }\end{array}$ \\
\hline Informal conversation & $\begin{array}{l}\text { Observe and eavesdrop, to share information about the words, sentences } \\
\text { and the emotion they put into it. }\end{array}$ \\
\hline Formal conversation & $\begin{array}{l}\text { Review a book, to share information about the formal words and } \\
\text { structures, talk about characters, role play and then write a review. }\end{array}$ \\
\hline
\end{tabular}

Table 3. Hughes' Scale for Scoring Writing.

\begin{tabular}{|c|c|c|}
\hline & Maximum score & Students score \\
\hline Topic sentence & 2 & \\
\hline Grammar & 6 & \\
\hline Mechanics & 2 & \\
\hline Fluency & 2 & \\
\hline Relevance & 6 & \\
\hline
\end{tabular}


Table 4. Group statistics and independent samples test

\begin{tabular}{|c|c|c|c|c|c|}
\hline \multicolumn{7}{|c|}{ Group Statistics } \\
\hline \multirow{3}{*}{ scores } & group & $\mathrm{N}$ & Mean & Std. Deviation & Std. Error Mean \\
\hline \multirow{2}{*}{} & experiment & 30 & 17.0000 & 1.02973 & .18800 \\
\cline { 2 - 6 } & control & 30 & 14.5917 & .71161 & .12992 \\
\hline
\end{tabular}

\begin{tabular}{|c|c|c|c|c|c|c|c|c|c|}
\hline \multicolumn{10}{|c|}{ Independent Samples Test } \\
\hline & \multicolumn{2}{|c|}{$\begin{array}{l}\text { Levene's Test for } \\
\text { Equality of } \\
\text { Variances }\end{array}$} & \multicolumn{7}{|c|}{ t-test for Equality of Means } \\
\hline & \multirow[t]{2}{*}{$\mathrm{F}$} & \multirow[t]{2}{*}{ Sig. } & \multirow[t]{2}{*}{$\mathrm{t}$} & \multirow[t]{2}{*}{$\mathrm{df}$} & \multirow[t]{2}{*}{$\begin{array}{c}\text { Sig. } \\
\text { (2-tailed) }\end{array}$} & \multirow[t]{2}{*}{$\begin{array}{c}\text { Mean } \\
\text { Difference }\end{array}$} & \multirow[t]{2}{*}{$\begin{array}{l}\text { Std. Error } \\
\text { Difference }\end{array}$} & \multicolumn{2}{|c|}{$\begin{array}{l}95 \% \text { Confidence } \\
\text { Interval of the } \\
\text { Difference }\end{array}$} \\
\hline & & & & & & & & Lower & Upper \\
\hline $\begin{array}{l}\text { Equal variances } \\
\text { not assumed }\end{array}$ & & & 10.539 & 51.555 & .000 & 2.40833 & .22853 & 1.94967 & 2.86700 \\
\hline
\end{tabular}

Table 5. Paired samples analysis of the experimental group

\begin{tabular}{|c|l|c|c|c|c|}
\hline \multicolumn{7}{|c|}{ Paired Samples Statistics } \\
\hline \multirow{3}{*}{ Pair 1 } & Mean & N & Std. Deviation & Std. Error Mean \\
\cline { 2 - 6 } & posttest of experimental group & 17.0500 & 30 & 1.01582 & .18546 \\
\cline { 2 - 6 } & pretest of experimental group & 14.1500 & 30 & 1.14771 & .20954 \\
\hline
\end{tabular}

\begin{tabular}{|c|c|c|c|c|c|c|c|c|c|}
\hline \multicolumn{10}{|c|}{ Paired Samples Test } \\
\hline & & \multicolumn{5}{|c|}{ Paired Differences } & \multirow{3}{*}{$\mathrm{t}$} & \multirow{3}{*}{ df } & \multirow{3}{*}{$\begin{array}{c}\text { Sig. } \\
\text { (2-tailed) }\end{array}$} \\
\hline & & \multirow{2}{*}{ Mean } & \multirow{2}{*}{$\begin{array}{c}\text { Std. } \\
\text { Deviation }\end{array}$} & \multirow{2}{*}{$\begin{array}{l}\text { Std. Error } \\
\text { Mean }\end{array}$} & \multicolumn{2}{|c|}{$\begin{array}{l}\text { 95\% Confidence Interval of } \\
\text { the Difference }\end{array}$} & & & \\
\hline & & & & & Lower & Upper & & & \\
\hline Pair 1 & $\begin{array}{l}\text { posttest of } \\
\text { experimental pretest of } \\
\text { experimental group }\end{array}$ & 2.90000 & .57084 & .10422 & 2.68684 & 3.11316 & 27.825 & 29 & .000 \\
\hline
\end{tabular}


Table 6. Paired samples analysis of the control group

\begin{tabular}{|l|l|r|r|r|r|}
\hline \multicolumn{7}{|c|}{ Paired Samples Statistics } \\
\hline \multirow{2}{*}{ Pair 1 } & Mean & N & \multicolumn{1}{c|}{ Std. Deviation } & \multicolumn{1}{c|}{ Std. Error Mean } \\
\cline { 2 - 7 } & posttest of control group & 14.6167 & 30 & .72139 & .13171 \\
\cline { 2 - 7 } & pretest of control group & 14.4667 & 30 & .77051 & .14067 \\
\hline
\end{tabular}

\begin{tabular}{|c|c|c|c|c|c|c|c|c|c|}
\hline \multicolumn{10}{|c|}{ Paired Samples Test } \\
\hline & & \multicolumn{5}{|c|}{ Paired Differences } & \multirow{3}{*}{$\mathrm{t}$} & \multirow{3}{*}{ df } & \multirow{3}{*}{$\begin{array}{c}\text { Sig. } \\
\text { (2-tailed) }\end{array}$} \\
\hline & & \multirow{2}{*}{ Mean } & \multirow{2}{*}{$\begin{array}{c}\text { Std. } \\
\text { Deviation }\end{array}$} & \multirow{2}{*}{$\begin{array}{l}\text { Std. Error } \\
\text { Mean }\end{array}$} & \multicolumn{2}{|c|}{$\begin{array}{l}\text { 95\% Confidence Interval of the } \\
\text { Difference }\end{array}$} & & & \\
\hline & & & & & Lower & Upper & & & \\
\hline Pair 1 & $\begin{array}{l}\text { posttest of control } \\
\text { group - pretest of } \\
\text { control group }\end{array}$ & .15000 & .40790 & .07447 & -.00231 & .30231 & 2.014 & 29 & .053 \\
\hline
\end{tabular}

\section{Appendix}

\section{Appendix 1. Questionnaire}

Questionnaire on selecting the topics, in order to identify some aspects related to the students' point of view about the class stages, the activities they liked the most, and the ones that helped them to become involved during the class process.

Dear students,

I would greatly appreciate your response to the following questions, which don't take much time, and are easy to answer. It is only for research purposes and has nothing to do with the evaluation of the course or the teacher. Do not write your name, teacher's name.

Q) Which topic do you like more to practice in the class?

1. Activities related to the predetermined topics by the teacher.

$\begin{array}{lc}\square \text { Yes } & \square \text { No } \\ \text { Yes } \square & \square \text { No } \\ \text { Yes } \square & \square \text { No } \\ \text { Yes } \square & \square \text { No } \\ \square \text { Yes } & \square \text { No } \\ \square \text { Yes } & \square \text { No } \\ \text { Yes } \square & \square \text { No } \\ \square \text { Yes } & \square \text { No }\end{array}$

2. Sensations and health habits.

3 . Some general problems in the society.

4. Activities related to formal conversations.

5. Activities that implies movement.

6. Soft drugs.

7. Activities related to formal conversations.

8. Free writing.

Appendix 2. Sample of a Lesson Plan

Session: Fourth

Levels: Intermediate

Topic: Routines and Daily Activities

Language Focus: To share information about routines and to identify specific information in a text

General Objective: To identify and use some expressions to talk about daily activities and routines Specific Objectives:

- To review specific vocabulary related to daily activities and routines

- To share information using drawings and expressions
Grade: sophomore EFL students

Time: 55 minutes 
- To identify specific information from a text

\section{Previous Knowledge:}

- Vocabulary about routines and daily activities

- Using some requests to get information, like: Do you have the picture of...? Would you like to share your picture with me? Let me see your picture, etc.

Materials: Pictures, pieces of paper using some expressions, photocopies.

\section{Organization:}

At the beginning students will be organized at random in order for them to find his/her partner.

Then they will work individually using the photocopy.

\section{Procedure:}

Warm up: Review the vocabulary about routine and daily activities using some pictures and their corresponding expressions. Students are divided into two groups. One looks at its pictures and tries to find the partner who has the right expressions. The other does the same, but using the expressions.

The pictures and expressions used for the activity are the following:
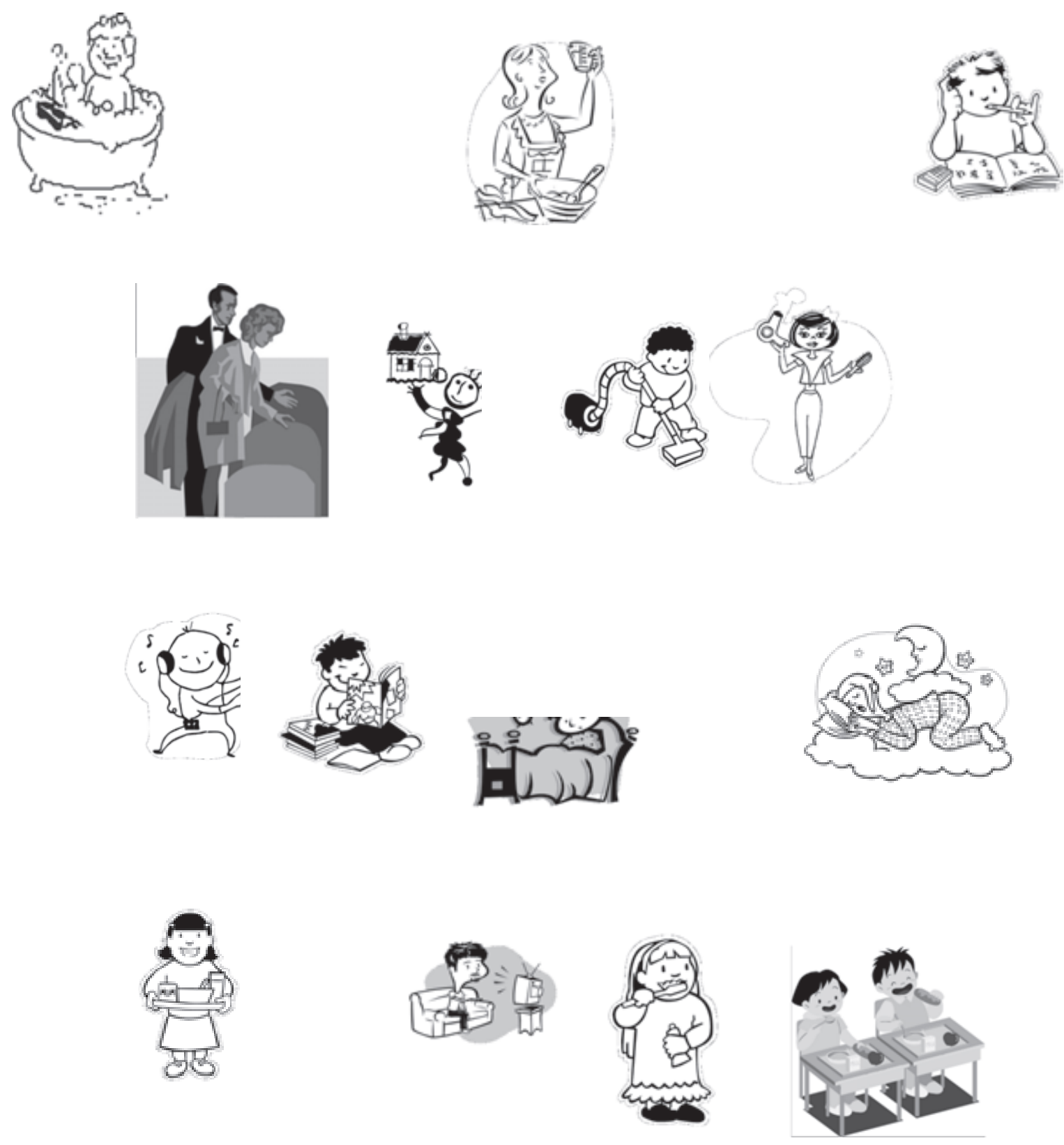


\begin{tabular}{|l|l|l|l|}
\hline Take a bath & Play soccer & Vacuum & Do homework \\
\hline Cook & Made the bed & Listen to music & Have breakfast \\
\hline Vacuum & Sleep & Watch TV & Read \\
\hline Listen to music & Get up at 8:00 a.m. & Sleep & Leave the house \\
\hline Watch TV. & Have lunch & Get up at 8:00 a.m. & Brush her hair \\
\hline Take a bath & Brush her teeth & Have lunch & Do homework \\
\hline Cook & Play soccer & Brush her teeth & Have breakfast \\
\hline Leave the house & Make the bed & Read & Brush her hair \\
\hline
\end{tabular}

The Role of Warming Up Activities in EFL Student's Involvement during the English Class

\section{Presentation:}

Based on the pictures and expressions they matched, students have to remember the useful expressions to express daily routines and activities.

\section{Practice:}

The teacher asks some questions about a partner they know. Then the teacher asks students to write a paragraph of about 150 words in 20 minutes about their routine and daily activities.

Production and evaluation: Teacher goes around to the small groups in order to help them with doubts or questions. 